\title{
Small Intestine Cancer pTis TNM Finding v7
}

National Cancer Institute

\section{Source}

National Cancer Institute. Small Intestine Cancer pT is TNM Finding V7. NCI Thesaurus.

Code C89867.

Small intestine cancer with a finding of carcinoma in situ. (from AJCC 7th Ed.) 